\title{
Syrien genfortalt
}

Den syriske tv-serie Haris al-Quds (Jerusalems vogter) fortæller historien om Hilarion Capucci (1922-2017), den kontroversielle syriskfødte ærkebiskop i Jerusalem, som var aktiv i den palæstinensiske modstandskamp. Serien illustrerer samtidig, hvordan den syriske stat forsøger at genfortælle Syrien som progressivt, anti-imperialistisk og religiøst tolerant.

af CHRISTINE ASTER CRONE

I denne artikel vil jeg med udgangspunkt i den syriske ramadantv-serie Haris al-Quds (Jerusalems vogter) fra 2020 genbesøge syrisk tv-drama og unders $\emptyset$ ge, hvilket Syrien det syriske styre fors $\varnothing$ ger at tegne et billede af efter ti år med fortsat krig. Gennem sine 30 afsnit fortæller serien historien om den kontroversielle syriske præst og senere ærkebiskop af Jerusalem, Hilarion Capucci (1922-2017); fra hans barndom i Aleppo i 1930’erne, til hans død i eksil i Rom d. 1. januar 2017. Capucci fungerer i vid udstrækning som en personificering af Syrien, og gennem hans livshistorie fortælles således Syriens moderne historie - fra tiden som fransk mandat til i dag som krigshærget land - hvor Levantens kristne (gen)indskrives i den nationale historiefortælling. Serien fortæller ligeledes historien om den palæstinensiske modstandskamp, når vi som seere følger, hvordan Capuccis voksende engagement for sagen tager form som organiseret modstandskamp, kulminerende med, at han som ærkebiskop af Jerusalem smugler våben til PLo ind over grænsen fra Libanon - indtil han i 1974 bliver pågrebet og fængslet. ${ }^{1}$ Hilarion Capucci blev idømt 12 års fængsel ved en israelsk domstol, men afsonede kun de fire. Vatikanet indgik en aftale med de israelske myndigheder om, at Capucci blev løsladt før tid på betingelse af, at han ikke længere var bosat $i$ et arabiske land - hvorfor han endte sine dage i eksil i Rom.

Haris al-Quds er skabt i en tid, hvor det syriske styre har genvundet den militære kontrol over store dele af landet, mens resultatet af 10 års krig og sanktioner har skabt et $\varnothing$ konomisk kollaps for st $\varnothing$ rstedelen af befolkningen. ${ }^{2}$ Det betyder, at den kamp, styret og mange oppositionsgrupper intenst har udkæmpet om krigens narrativ - om hvorvidt der er tale om et brutalt regime, der hensynsløst nedkæmper sin egen befolkning, eller om en progressiv stat, der kæmper mod en 


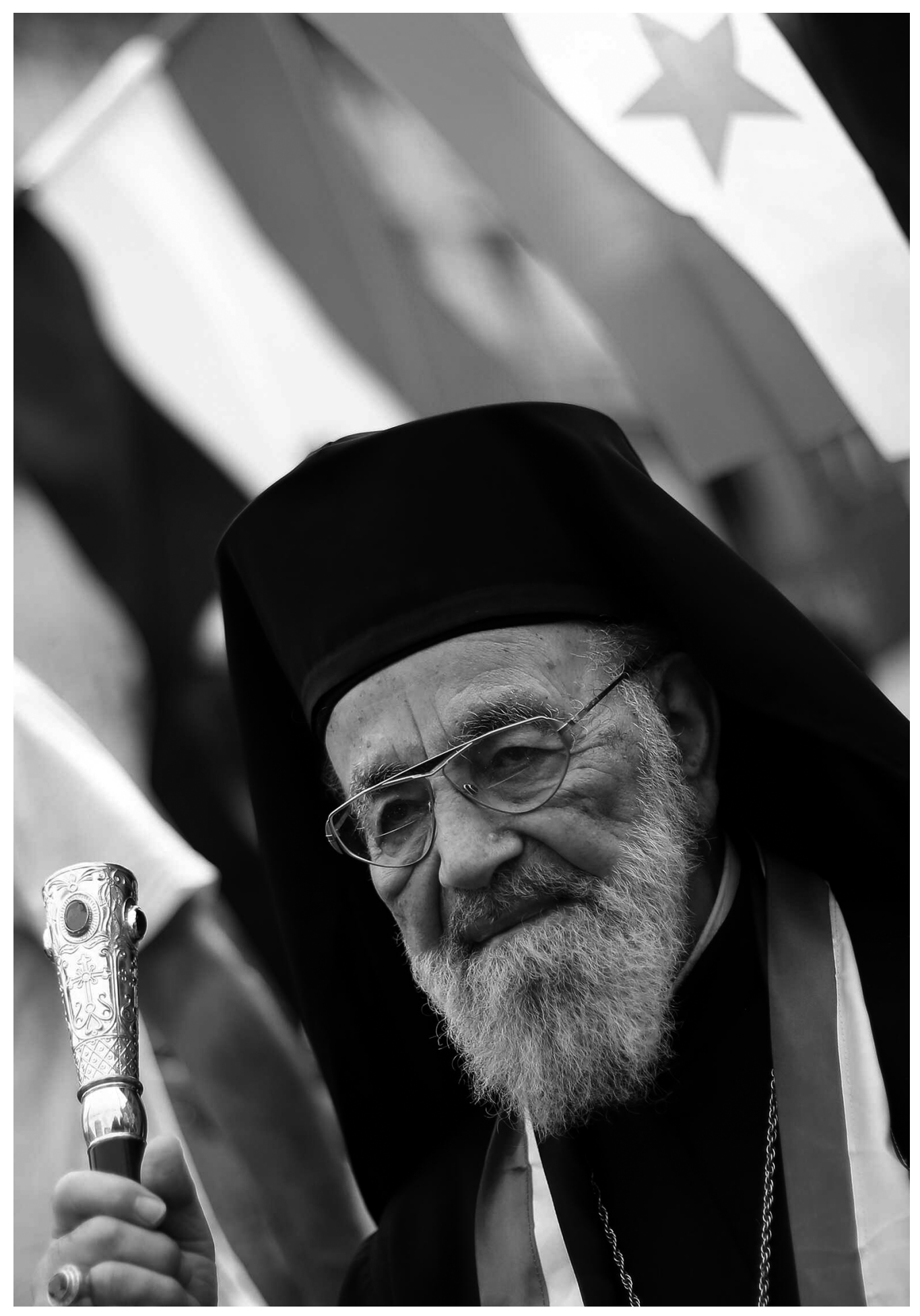


voldelig islamistisk opposition styret og finansieret af udenlandske fjendtlige kræfter - har mistet sin aktualitet. Det betyder ligeledes, at alAssads tidligere image, som garant for «det gode liv» i Syrien for længst er gjort til skamme. Haris alQuds er således et eksempel på, hvordan styret nu fors $\emptyset$ ger at genfortælle - eller genopfinde - sig selv ved at tage styring med og monopolisere fortællingen om, hvilket Syrien der var, og hvilket Syrien, der er ved at tage form.

Hvis vi spoler tiden tilbage til år 2000, hvor verden trådte ind $i$ et nyt årtusinde, trådte Bashar al-Assad til som præsident i Syrien efter sin fars $\mathrm{d} \varnothing \mathrm{d}$. Her 20 år senere ser meget anderledes ud, end de fleste af os nok havde forestillet os dengang, hvor også Det Danske Institut i Damaskus blev etableret i det gamle hus Bait al-'Aqqad med formålet om kulturelt og videnskabeligt samarbejde. Selvom initiativet til Instituttet blev taget før lederskiftet i Syrien, faldt Instituttets åbning i tråd med den generelle stemning, der prægede landet $\mathrm{i}$ 2000 om fornyet åbning og dialog. Da Bashar alAssad kom til magten, havde mange forhåbninger om, at den unge præsident ville lede Syrien i en mere demokratisk retning. Dette blev ikke mindst understøttet af hans lancering af sig selv som den moderne og liberale arvtager samt det efterfølgende såkaldte Damaskus-forår, hvor systemkritikere og andre oppositionelle stemmer pludselig kom til orde. Men ligeså uvant det nye politiske spillerum var, ligeså hurtigt blev det også lukket ned igen, da Bashar al-Assad justerede sine ambitioner for reformer i Syrien.

Da den første forårsrus havde lagt sig, og hverdagen igen meldte sig, blev det klart at den unge præsident prioriterede $\varnothing$ konomisk over politisk liberalisering. ${ }^{3}$ Dette betød pleje af den nye middelklasse, der voksede frem på bekostning af de socialistiske idealer fra hans fars tid og promoveringen af sig selv som garant for indfrielsen af «det gode liv». Forestillingerne om «det gode liv» omfattede ikke kun økonomisk fremgang, den unge al-Assad udskiftede ligeledes tidligere tiders ideologiske paroler om panarabisk solidaritet med slogans, der promoverede en Syrien-først agenda. ${ }^{4}$ Eller som Lisa Wedeen formulerer det: «Syria’s good life entailed not only the usual aspirations to economic well-being, but also fantasies of multicultural accommodation and a secure, sovereign, pride-inducing national identity.» 5

$\mathrm{Ti}$ år senere, da folkelige protester og begyndende revolutioner tog om sig i den arabiske verden, og i marts 2011 også manifisterede sig i Syrien, holdt mange vejret. Hvordan ville Bashar al-Assad respondere på kravet om politisk forandring? Det syntes at være hans sidste chance for at honorere de forventninger, der stadig florerede omkring ham og omkring endnu uforløste demokratiske visioner. Ville han anderkende behovet for

$$
\text { ๑๑ }
$$

I Bashar al-Assads første ti år ved magten syntes der at være en umiddelbar overensstemmelse mellem hans politiske ambitioner og dramaskabernes idealer.

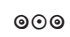

forandring og invitere de kritiske røster indenfor til dialog? Få minutter efter at al-Assad gik på talerstolen d. 30 marts 2011 for at adressere udviklingen i landet, stod svaret klart. Resten er historie nu, eller rettere sagt: resten er den virkelighed, syrere lever i og med hver dag, i dag.

\section{Syrisk tv-drama}

Tv-drama har gennem mange år været en relevant scene at vende blikket mod, hvis man $\emptyset$ nsker at forstå politiske udviklinger og dynamikker i Syrien ikke mindst efter Bashar al-Assad kom til magten, har det været et afgørende forum for politisk kommunikation og forhandling. Samtidig har genren udviklet sig til et iøjnefaldende arabisk mediefænomen og et vigtig syrisk kulturelt eksport- 
produkt. Paradoksalt nok er en af forklaringerne på tv-dramaets succes, at produktionen af syrisk tv-drama fra sin spæde start i 1960'erne var karakteriseret af manglende finansiering og dårlig infrastruktur. ${ }^{6}$ Netop disse strukturelle svagheder har været med til at forme den nu velkendte og berømte syriske dramastil. Manglen på filmstudier flyttede optagelserne ud «on location», fraværet af en konkurrerende filmindustri skubbede talentfulde instruktører (ofte uddannede i Sovjet) over i tv-dramaproduktionen, ligesom den strenge censur af ikke-fiktion gjorde det attraktivt for politisk engagerede forfattere at skrive manuskripter til tv-drama.7 Selvom syrisk tv-drama byder på mange forskellige genrer - fra socialrealisme til komedier og fra historiske dramaer til romantiske melodramer - er et fællestræk ved dem, at de ofte har en social eller politisk kant. Mens denne karakteristiske syriske dramaproduktion begyndte at tage form, opstod der samtidigt et nyt og attraktivt marked for tv-serier, i takt med at antallet af arabiske (ofte Golf-ejede) satellitkanaler eksploderede op gennem 1990'erne. I 2011, da de første folkelige protester tog form, blev der i gennemsnit produceret omkring $50 \mathrm{tv}$-dramaer årligt i Syrien. ${ }^{8}$

Dette succesfulde kulturprodukt har ligeledes under Bashar al-Assad udgjort en vigtig brik i hans navigation mellem opretholdelsen af censur og tabuemner på den ene side, og behovet for at kommunikere moderne lederskab med plads til kritiske røster på den anden side. Der udviklede sig således en strategisk alliance mellem Bashar alAssad og tv-dramamiljøet, som hvilede på en fælles forståelse af, at man sammen kunne skabe en progressiv udvikling af både landet og befolkning gennem oplysning og gradvise politiske reformer. ${ }^{9}$ I den syriske tv-dramaindustri var gamle idealer om at uddanne og modernisere befolkningen en motivationsfaktor, og mange fra miljøet så sig selv garanter for en fortsat formidling af sekularisme og progressive politiske og sociale agendaer i en medievirkelighed, der i stigende grad er domineret af Golf-penge og salafistiske værdier. ${ }^{10}$

I Bashar al-Assads første ti år ved magten syntes der at være en umiddelbar overensstemmelse mellem hans politiske ambitioner og dramaskabernes idealer. Et begreb som tanwir ${ }^{11}$ (oplysning) og opfattelsen af, at topstyrede, elitedrevne reformer var vejen frem, var grundlæggende for en fælles forståelse af politiske prioriteringer. ${ }^{12}$ Denne (nogle gange direkte og andre gange indirekte) samarbejdsform omtaler Donatella Della Ratta som «the whisper strategy». Hun forklarer: «through the whisper strategy, the reformminded side of the regime ensures that issues of its concerns are communicated to the drama makers - and the other way around - and discussed in edgy television dramas [...].». ${ }^{13}$ Tv-drama udviklede sig således til en platform, hvor man kunne diskutere både sociale, politiske, religiøse og historiske emner inden for rammerne af syrisk national censur og markedets (Golfstaternes) konservative normer. Ifølge Christa Salamandra bliver dette ofte gjort med udgangspunkt $i$ «what went wrong», hvor syriske dramaproduktioner (både før og efter 2011) undersøger misforholdet mellem Ba'ath-systemets løfter om modernitet og den erfarede virkelighed med et samfund, som dramaproducenterne stadig opfatter som værende tilbagestående. Således diskuteres alt fra kritisable boligforhold, korruption, konservative familienormer og manglende mulighed for selvrealisering, mens de bagvedliggende årsager identificeres som fortidens forfejlede og forspildte politiske muligheder. ${ }^{14}$

Til trods for at krigen ikke har lukket (kritisk) syrisk tv-drama helt ned, har den sat sit præg på industrien. Ikke bare er finansieringsmulighederne skrumpet ind som resultat af regional boykot, ${ }^{15}$ hvormed antallet af årlige produktioner er blevet halveret-også hele produktionsmiljøet er præget 
af politisk splittelse og uenighed om, hvordan man skal forholde sig til den eskalerende statsvold. Hvor nogle åbent har støttet oprørene og i dag lever i eksil uden for Syrien, er majoriteten forblevet loyale over for det politiske system og den uofficielle samarbejdsstrategi med al-Assad. ${ }^{16}$ Det er i denne kontekst af opbrud og sammenbrud, at Haris al-Quds er produceret.

Haris al-Quds er instrueret af den syrisk-palæstinensiske filminstruktør Basil al-Khatib, som er et klart eksempel på en fra tv-dramamiljøet, der er forblevet loyal over for styret. Dette blev belønnet i 2021, da han blev udnævnt til dekan for det nyligt oprettede statslige Higher Institute of Cinematic Arts. ${ }^{17}$ Serien er derudover finansieret af det statslige organ The Syrian General Organization for the Production of Television and Radio modsat størstedelen af syrisk tv-drama, der typisk har private investorer i ryggen. At serien falder indenfor styrets agenda, bekræftes yderligere af det officielle syriske nyhedsbureau SANA, der omtaler serien som organisationens hidtil både største og vigtigste produktion. ${ }^{18}$

Serien blev, som den første (og indtil nu eneste) dramaproduktion, vist på den al-Assad-loyale nyhedskanal, al-Mayadeen, hvor den udgjorde ramadanunderholdningen i 2020 . Her bidrog den med en dramatisering af kanalens grundlæggende ideologiske positioner, hvad jeg, andetsteds, kalder «The New Regressive Left». ${ }^{19 / 20}$ En ideologisk diskurs, der promoverer «old school» antiimperialisme med en genlancering af kampen for Palæstina svøbt i nostalgi og autoritære værdier. På denne (formentligt) Iran-finansierede kanal genforhandles kategorier som «progressiv» og «regressiv», når ekkoer af venstrefløjens progressive idealer resulterer i regressive politikker. Så mens folkelige revolutioner hyldes, fordømmes «det arabiske forår»; og når kampen mod vestlig imperialisme skal vindes, er det bedste våben en stærk leder og ukritisk patriotisme. ${ }^{21}$
Haris al-Quds er på mange måder et produkt af den velkendte syriske dramatradition. Optagelserne er foregået forskellige steder i Syrien fremfor i filmstudier, og krigshærgede Aleppo udgør således en tilbagevendende kulisse for fortællingen. Ligeledes trækker serien på den syriske tvdramatraditionen for at ville mere end «blot» underholdning. Men modsat tidligere produktioner er kritisk samfundsdebat og national selvrefleksion ikke en underliggende nerve - en potentiel indikation på et nyt og indskrænket rum for national politisk debat. Det kritiske spørgsmål «What went wrong?» som Salamandra identificerer, bliver i Haris al-Quds nærmere til det retoriske spørgsmålet «What went right?»22 Dette uddyber jeg i de efterfølgende afsnit, hvor jeg undersøger, hvordan serien fremstiller i) styrets generobring af Aleppo som modernitetens genkomst til Syrien, ii) Syrien som regionalt centrum og iii) Bashar al-Assad som minoriteternes vogter og beskytter.

\section{Befrielsen af Aleppo}

Haris al-Quds begynder i Rom, hvor vi møder Hilarion Capucci fordybet i bøn, gammel og skrøbelig en aften ved sit hjemmealter. Kort efter får han et telefonopkald fra sin barndomsby med besked om, at Aleppo er «befriet» ${ }^{23}$, altså genindtaget af regeringstropperne. Den gamle mand synker sammen i lettelse, og med et lykkeligt udtryk i $\emptyset$ jnene vandrer hans tanker gennem aftenmørket og voldsomt regnvejr til Aleppo. Her klipper fortællingen til Aleppo - hvor det også er mørkt og regnfuldt - og vi ser hæren bevæge sig gennem byen i et sejrsoptog. I næste scene er vi tilbage $\mathrm{i}$ Rom, hvor Capucci får besøg af to lokale kirkegængere, Rima og hendes mand, som fortæller at Rima har besluttet at rejse tilbage til Aleppo for at besøge sin mor, nu hvor byen er befriet. Senere, da Capucci sidder alene tilbage, vælder barndomsminderne fra Aleppo ind over 
ham, og vi møder ham som 11-årige George hjemme hos sin mor i deres traditionelle arabiske hus og i sin (kristne) skole med sin bror. Således er seerne præsenteret for de tre vigtigste fortællerlinjer, som serien er bygget op omkring: I) Capuccis sidste dage i Rom fra Aleppos «befrielse» d 22. december 2016 til hans død den 1. januar 2017, II) hans livshistorie som fortælles kronologisk i form af flashbacks, og III) livet $\mathrm{i}$ Aleppo i 2020, som fortælles gennem Rimas rejse tilbage til sin barndomsby.

Aleppo spiller en gennemgående og central rolle i Haris al-Quds. Ikke bare er det Capuccis barndomsby og dermed en kilde til nostalgi for en tid, hvor syrere kæmpede mod den franske kolonimagt, «befrielsen» af Aleppo i 2016 igangsætter hele serien og muligg $ø$ r en fortælling om et fremtidigt Syrien igen under al-Assads fortsatte kontrol. Aleppo som omdrejningspunkt åbner ligeledes op for at berøre en af krigens vigtigste og værste kamppladser - kampen om byen var lang og hård, og det militære udfald var både af stor strategisk og symbolsk betydning for alle parter. ${ }^{24}$ Styrets generobring blev således et vigtigt vendepunkt i krigen, som knækkede forestillingen om et egentligt alternativ til Ba'ath partiet og alAssad-familien. Det bekræftede ligeledes styret i, at krigen var en tidsafgrænset krise, og at genetablering af kontrol var en reel mulighed. I serien kommer byen således til at fungere som et symbol på hele Syriens og Ba'ath-styrets skæbne.

Dette til trods er befrielsesscenen bemærkelsesværdig dyster. Holdt i kolde mørke farver og optaget i voldsomt regnvejr står det ikke klart ved første $\varnothing$ jekast, om det er en festens eller sorgens dag. Først ved nærmere eftersyn bliver det tydeligt, at folk i baggrunden jubler, og at de marcherende soldater fremstilles som befriere. Til trods for sejren hviler ti års ødelæggelser over byen. At krigen har været hård og folket har lidt kan ikke skjules, men kræver anerkendelse. Modsat Ba'ath- styrets strategi efter bombningen af Hama i 1982, hvor sporene hurtigt blev slettet og episoden tabuiseret, ${ }^{25}$ er $\emptyset$ delæggelserne, sorgen og de menneskelige omkostninger synlige i Haris alQuds. Serien berører derimod ikke den politiske diskussion om, hvorfor og hvordan landet er endt i denne situation - her findes kun én relevant udlægning, nemlig at styrets generobring af Aleppo må forstås som «befrielsen».

Det er Rimas ankomst til Aleppo, som giver anledning til en panorering over og dvælen ved $\emptyset$ delæggelserne, ikke mindst når seerne følger Rimas gensyn med sin by, hvor de velkendte billeder af Aleppo i ruiner udg $\varnothing \mathrm{r}$ en vigtig kulisse. Det er også i en af disse scener, at det står klart, at Rimas tilbagevenden til Aleppo ikke blot markerer afslutningen på en militærkonflikt, men også modernitetens og civilisations genankomst til Syrien. I en af de første scener, hvor Rima er tilbage i byen, vandrer hun rundt i de $\varnothing$ delagte gader sammen med en veninde. Begge kvinder er unge og signalerer modernitet med udslået hår, høje hæle og Rima i en elegant knaldrød jakke. Hun er selvfølgelig dybt berørt over at se sin barndomsby totalt ødelagt, men midt i sorgen skabes et stærkt billede af, at fremtiden er vendt tilbage til Aleppo. Tilbagestående og undertrykkende kræfter er fordrevet, og i stedet er der skabt plads til modernitetens genkomst i form af to selvstændige kvinder, der genindtager gaderne.

Det er ligeledes Rima, der bringer humanisme tilbage til Aleppo, når hun som den eneste forfærdes over mødet med en forældrel $\varnothing$ s og hjemløs lille pige på gaden. Mens hendes mor og veninde fejer det af med, at «dem er der så mange af», bliver Rima dybt påvirket af oplevelsen - som ikke var normalitet tidligere i Syrien - og ender med at tage pigen med hjem til sin mor. Moren er langt fra begejstret, og veninden ser hovedrystende til, men Rima insisterer på at tage pigen til sig. Således skabes en fortælling om den forråelse, der fandt 
sted i Aleppo, mens byen var uden for styrets kontrol - og som står i skærende kontrast til de humanistiske værdier, der nu kan genetableres efter byens «befrielse».

\section{Kampen for Palæstina}

Et vigtigt og gennemgående element i fortællingen - og det, der gennem tiden har gjort Capucci til en både kontroversiel og værdsat figur - er hans engagement i den palæstinensiske modstandskamp mod Israel. Allerede i de første scener, hvor Capucci optræder som skoledreng i Aleppo og siden som den unge præstestuderende, først i Libanon og senere Palæstina, fremstår indignationen over uretfærdighed og undertrykkelse som et vigtigt kompas i hans liv. Igen og igen tager han aktivt del i kampen mod undertrykkelse - uanset om den kommer i form af fransk kolonialisme eller israelsk besættelse. Denne klare ideologiske position bruges ikke kun til at idealisere Capucci, men også til at placere hans udtalte støtte til Bashar al-Assad inden for et bestemt narrativ, nemlig den fortsatte kamp mod imperialismen. Al-Assads kamp mod en hver form for oppositionskræfter i Syrien bliver således rammesat som en naturlig fortsættelse af tidligere og nuværende modstandskampe i regionen. Oppositionsgrupperne, derimod, er skrevet ud af historien og figurerer blot som en samlet udefinerbar ondskab, der nu er fordrevet.

Mens Aleppo bliver et billede på Syrien efter borgerkrigen, hvor hærens og Rimas tilbagevenden signalerer civilisationens og modernitetens genoprettelse, spiller Jerusalem en anden og ligeledes vigtig rolle for genfortællingen af Syrien. Her bliver Capucci, Jerusalems vogter (som jo er titlen på serien), et vigtigt symbol på det Syrien som serien gerne vil (gen)etablere. Capucci iscenesættes som vogter - eller flokkens hyrde allerede i de første afsnit, hvor han som skoledreng har en snak med sin mormor, der forklarer ham, at mennesker typisk er enten får eller ulve, men at nogle få også kan få rollen som hyrde. Hun beder ham tænke over, hvilken type menneske han selv $\emptyset$ nsker at være. Ved en senere lejlighed, efter han har tænkt mormorens ord igennem, proklamerer han, at han vil være hyrden. Ligeledes får vi også forklaret at hans efternavn, Capucci, betyder vogter, hvilket kun understreger hans (Syriens) naturlige rolle som flokkens hyrde.

Med denne udtalte ambition rejser den unge George først til Libanon og senere til Palæstina for at forfølge præstestudiet. Capucci er et produkt af sin tid, inden nationer og statsborgerskaber begyndte at opdele Bilad al-Sham [Levanten] og områdets befolkning. Han orienterer sig på tværs af landegrænser og giver ofte udtryk for, at for ham er Palæstina og Syrien ét og samme land, og han føler et åbenlyst ansvar for hele områdets skæbne. Som præstestuderende i Libanon bliver han draget mod Palæstina i frustration over den zionistiske indvandring, og efter sin ankomst til Jerusalem bliver han bekræftet i situationens alvor. Han kommer i kontakt med en lokal palæstinensisk kvinde, og da hun og hendes søn i 1948 drives på flugt og må forlade deres hus, overlader hun sin nøgle i Capuccis varetægt. Historien trækker her på nøglen som et velkendte symbol for palæstinensernes kamp for retten til at vende tilbage til deres land, som de måtte flygte fra med Israels oprettelse. ${ }^{26}$ Det ligger nu i Capuccis (Syriens) hænder at realisere hjemkomsten til Palæstina.

Denne nøgle, sammen med en kniv, han ved en anden lejlighed har hjulpet en ung palæstinensisk modstandsmand med at gemme af vejen for britisk politi, fungerer som et pejlemærke for hans virke. Igen og igen vender han tilbage til disse to genstande og mindes, hvordan han fik dem i sin varetægt - man fornemmer det ansvar, han føler for at videreføre kampen for Palæstina. Dette bringer os til en af seriens vigtigste fortællinger om Syrien, nemlig genetableringen af Syrien som be- 
skytter og vogter af Bilad al-Sham og ikke mindst en genlancering af Syrien i rollen som Palæstinas primære forkæmper. Således bliver «befrielsen» af Aleppo også en fortælling om, at al-Assad lykkes militært, og at næste skridt potentielt kunne være befrielsen af Jerusalem.

Hvor Hafiz al-Assad prioriterede forestillingen om Syrien som en central brik i en stor panarabisk drøm, og Bashar al-Assad modsat vendte fokus mod en fortrinsvis syrisk national identitet i sine første år ved magten, bidrager Haris al-Quds til en forestilling om et særligt levantisk fællesskab med Syrien som leder og beskytter. Denne tanke er ikke ukendt, men har tidligere først og fremmest været dyrket af ssNP, The Syrian Social Nationalist Party. ${ }^{27}$ SSNP, der var forbudt i Syrien siden 1955 , blev legaliseret af Bashar al-Assad i 2005, hvorefter partiet blev en del af det officielle politiske liv i Syrien. Under borgerkrigen har partiet vundet yderligere styrke og indflydelse og har spillet en aktiv militær rolle i form af pro-al-Assad militser. ${ }^{28}$ Idéen om Bilad al-Sham med Syrien som det naturlige centrum og som modstykke til Golfen bliver også promoveret på al-Mayadeen. ${ }^{29}$ Fælles for den forestilling, som kommer til udtryk i Haris alQuds og på al-Mayadeen, er en forståelse af Bilad al-Sham, som bærer af civilisation og religiøs tolerance samt som værende den sidste arabiske bastion i kampen mod Israel og vestlig imperialisme.

\section{Religiøs pluralisme og sameksistens}

Et tredje vigtigt aspekt i Haris al-Quds er kristendommen og med den promoveringen af religiøs tolerance og pluralisme. Kristne og kristendom spiller oftest en lille rolle i arabiske mainstream medier, og selvom kristne tidligere har figureret $\mathrm{i}$ syrisk tv-drama, har det været i begrænset omfang. Et sted, hvor kristne derimod finder rum, er på alMayadeen, der vægter at gøre kristne i Mellemøsten synlige og give dem stemme. Mest oplagt i det ugentlige program om kristne og kristendom i regionen, Ajras al-Mashreq (Levantens klokker), men også bredere i stationens generelle promovering af religiøs pluralisme. ${ }^{30}$ Så selvom Haris al-Quds skiller sig ud fra den typiske ramadanunderholdning med sit fokus på at (gen)indskrive kristne som en central del af regionens identitet, falder serien godt $i$ tråd med al-Mayadeens agenda.

Gennem fortællingen om Capucci etableres fortællingen om kristne som patriotiske syrere (modsat forestillingen om kristne som værende mere loyale overfor Vesten end overfor den arabiske verden). Kristne ses som aktive deltagere $\mathrm{i}$ modstandskampen (modsat de seneste årtiers islamisering af denne), og hvis lange religiøse og kulturelle historie er vævet ind $i$ resten af regionens historie (modsat forestillingen om den arabiske verden som sunnimuslimsk). Denne promovering af kristne spiller ind i flere politiske dagsordener. For det første er det en vigtigt brik i det syriske styres lancering af sig selv som det progressive og inkluderende alternativ til Golfstaternes regressive og ekskluderende islamisme. For det andet taler det ind i Bashar al-Assads iscenesættelse af sig selv som beskytter (eller vogter) af religiøse minoriteter. Og for det tredje er det en anerkendelse af de syriske kristnes overvejende loyalitet overfor styret under borgerkrigen.

Lige siden Ba'ath-partiet kom til magten i Syrien - i høj grad båret frem af religiøse minoriteter, der blev tiltrukket af partiets sekulære ideologi - har styrets sekteriske karakter været diskuteret. Mens nogle iagttagere har vægtet styrets historiske inkorporation af sunni-bourgeoisiet $\mathrm{i}$ magtstrukturen gennem fælles $\varnothing$ konomiske interesser (og dermed nedtonet betydningen af sekterisme), har andre betonet, hvordan religiøse minoriteter generelt og dele al-Assad familiens egen Alawi-sekt i særdeleshed privilegeres i både 
politiske, $\varnothing$ konomiske og militære kontekster. ${ }^{31}$ Uanset hvordan man vægter sekterismens rolle, har emner som religiøse tilhørsforhold og religiøse minoriteter været tabuiseret i Syrien. Mens det har været et $\emptyset$ mtåleligt emne for al-Assad familien, at den ikke repræsenterede landets religiøse majoritet, har de brutale erfaringer med sekterisme i Libanon og sidenhen Irak underst $\varnothing$ ttet tabuiseringen. ${ }^{32}$ Siden de første demonstrationer i Syrien i 2011 har styret valgt en ny strategi, hvor det aktivt taler en sekterisk dagsorden op for at miskreditere oppositionen (som en samlet enhed). ${ }^{33}$ Til trods for at man i en syrisk sammenhæng ikke kan tale om en samlet opposition, er det netop dette styret gør. I spørgsmålet om sekterisme og minoriteter betyder det, at de mange forskellige positioner udviskes for at skabe en fortælling om én intolerant jihadistisk opposition, som systematisk forfølger religiøse minoriteter. Denne strategi, hvor der ikke skelnes mellem forskellige oppositionsgrupper, skaber således ikke blot en (misvisende) fortælling om en samlet intolerant opposition, men promoverer også styret som den civiliserede og tolerante garant for minoriteternes sikkerhed. En fortælling som landets religiøse mindretal i stor udstrækning - og til trods for at også oppositionelle stemmer blandt minoriteterne undertrykkes og forfølges - har valgt at acceptere. Bashar al-Assad som de religiøse minoriteters vogter er således en central fortælling i det nye Syrien, serien konstruerer.

\section{Syrien genfortalt}

I foråret 2020, på et tidspunkt hvor Syrien kæmpede med krig, ødelæggelser, fordrivelser - og hvor Det Danske Institut i Damaskus havde stået aflåst og tomt i noget, der nærmede sig et årti kæmpede produktionsholdet med at få Haris alQuds klar til ramadanen. Da der var tale om Syriens største statslige tv-satsning, blev alle kræfter sat ind, og Haris al-Quds rullede, som planlagt (trods
Covid-19 og deraf følgende logistiske udfordringer) over skærmen hjemme hos de seere, der tændte for al-Mayadeen om aftenen efter iftar. De, der fulgte serien, fik ikke blot indsigt i en kontroversiel og karismatisk kristen figur. De blev også præsenteret for, hvordan den syriske stat fors $\emptyset$ ger at tegne nationens historie og skabe forestillinger om et Syrien på den anden side af krigen. Selvom den palæstinensiske modstandskamp er helt central for fortællingen i Haris al-Quds, fremstår den alligevel som et sekundært aspekt - nærmest som en løftestang for den egentlige ambition med produktionen: (gen)fortællingen af Syrien. Her træder tre tydelige temaer frem, nemlig: Ba'athstyrets (potentielle) sejr som udtryk for at modernitet og progressive kræfter vandt over «de mørke kræfter», Syrien som centrum for og vogter af Bilad al-Sham, og Bashar al-Assads rolle som beskytter af områdets religiøse minoriteter og dermed garant for sameksistens og pluralisme.

Alle tre temaer er velkendte emner eller dilemmaer i Ba'ath-Syriens historie. For det første har modernitetsidealerne været en grundsten for det primært sekulære og socialistisk inspirerede parti, hvor modernitet under Bashar al-Assad i højere grad kom til at handle om «det gode liv». For det andet har Syriens panarabiske identitet over for landets nationale identitet løbende været til forhandling. Under Bashar al-Assad blev det tydeligt, at den panarabiske retorik blev nedprioriteret til fordel for sloganer om «Syrien først», men i 2020 kunne meget tyde på, at strategien for at genetablere forestillingen om Syriens storhed bygger på igen at indskrive landet som en del af noget større. Denne gang er visionen dog mere regionalt fokuseret i form af forestillingen om Syrien som det naturlige og historiske centrum for og beskytter af Bilad al-Sham. For det tredje har de religiøse minoriteters ambivalente, men centrale rolle for styret både været en vej til magten og udgjort en indbygget svaghed for 
styret. Tidligere tiders tabuisering af emnet, og de seneste ti års opildnen til sekterisme, er i 2020 afløst af en strategisk promovering af religiøse minoriteter som symbol på Syriens civilisation og af al-Assad som «hyrde» og vogter af denne civilisation.

Modsat andre dramaproduktioner, der kritisk har udforsket spørgsmålet om «what went wrong» og fandt svaret i fortidens uforløste potentiale og styrets manglende realisering af dets proklamerede ambitioner, fungerer fortiden i Haris alQuds som et ideal. Ikke fordi der ikke var konflikter, men fordi konflikterne var eksemplariske. Eksemplariske på grund af den ukomplicerede fortælling om patriotisme og heltemod som de primære våben i kampen mod udenlandske imperialistiske kræfter. Således kommer den syriske modstandskamp mod den franske kolonimagt og den palæstinensiske modstandskamp mod den israelske besættelsesmagt til at fungere som et sammenhængende narrativ, der sætter rammen for hvordan den nuværende krig i Syrien skal forstås. Nemlig som en direkte fortsættelse af den patriotiske kamp mod udenlandsk imperialisme - hvor den syriske hær heroisk kæmper for at befri landet fra denne undertrykkende kraft.

$$
\cdot f \cdot
$$

1 Hilarion Capucci blev idømt 12 års fængsel ved en israelsk domstol, men afsonede kun de fire. Vatikanet indgik en aftale med de israelske myndigheder om, at Capucci blev løsladt før tid på betingelse af, at han ikke længere var bosat $i$ et arabiske land - hvorfor han endte sine dage i eksil i Rom.

2 Dette er yderligere forværret af et den $\varnothing$ konomiske krise i Libanon, se fx mei.edu/publications/how-crisislebanon-impacting-syrias-economy og COVID-19pandemien, se fx: library.fes.de/ pdf-files/bueros/ beirut/16320.pdf

3 Volker Perthes, Syria under Bashar al-Asad:Modernisation and the Limits of Change (London: Routledge, 2005).

4 Yassin Al-Haj Saleh, Impossible Revolution: Making Sense of the Syrian Tragedy (London: Hurst, 2017).
5 Lise Wedeen, Authoritarian Apprehensions: Ideology, Judgment, and Mourning in Syria (Chicago: The University of Chicago Press, 2019), 20.

6 Alexandra Buccianti, «Arab Storytelling in the Digital Age: From Musalsalât to Web Drama?», i The State of PostCinema: Tracing the Moving Image in the Age of Digital Dissemination, red. Malte Hagener, Vinzenz Hediger og Alena Strohmaier (UK: Palgrave Macmillan, 2016).

7 Christa Salamandra, «Past Continuous: The Chronopolitics of Representation in Syrian Television Drama», Middle East Critique, 28:2 (2019).

8 Salamandra, »Past Continuous: The Chronopolitics of Representation in Syrian Television Drama», 124.

9 Donatella Della Ratta, «Making Real-Time Drama: The Political Economy of Cultural Production in Syria's Uprising», CARGC paper 6 (2014); Elizabeth Suzanne Kassab, Enlightenment on the Eve of Revolution (Columbia: Columbia University Press, 2019).

10 Christa Salamandra, «Creative Compromise: Syrian Television Makers between Secularism and Islamism», Contemporary Islam 2 (3): 177-189.

11 Tanwir har været et central begreb for den syriske opposition gennem flere årtier, i kampen for viden, oplysning og frihed og mod ignorance og undertrykkelse. Elizabeth Suzanne Kassab omtaler denne intellektuelle diskurs som «political humanism» og argumenter for at den har været central både i en egyptisk kontekst som modvægt til den islamistiske bevægelse og i en syriske kontekst som modvægt til et undertrykkende politisk system (Kassab 2019). Det er elementer af denne oppositionelle diskurs som indarbejdes og adresseres i de syriske dramaproduktioner.

12 Donatella Della Ratta, Shooting a Revolution: Visual Media and Warfare in Syria, (Pluto Press, 2018), 18.

13 Ratta, «Making Real-Time Drama: The Political Economy of Cultural Production in Syria's Uprising», 8.

14 Salamandra, «Past Continuous: The Chronopolitics of Representation in Syrian Television Drama».

15 I november 2011 suspenderede Den Arabiske Liga Syrien som medlem ligesom Ligaens medlemslande indførte diplomatiske og $\emptyset$ konomiske sanktioner over for Syrien. Begge dele på baggrund af den eskalerende statsvold. Selvom sanktionerne ikke har været overholdt lige stramt af alle medlemslandene har politiske spændinger begrænset investeringer i syrisk tv-drama.

16 Ratta, Shooting a Revolution; Salamandra, «Past Continuous: The Chronopolitics of Representation in Syrian Television Drama»; Omar Al-Ghazzi, «Nation as Neighborhood: how Bab al-Hara dramatized Syrian identity», Media, Culture \& Society, 35, 5 (2013).

17 arabic.rt.com/culture

18 sana.sy/en/?p=192320 
19 En ideologisk alliance, som er opstået mellem dele af den sekulære arabiske venstrefløj, Levantens religiøse minoriteter og det iranske præstestyre, først og fremmest drevet af en fælles frygt for Saudi Arabiens voksende indflydelse - både politisk, økonomisk og kulturelt.

20 Christine Crone, Pan-Arab News TV Station al-Mayadeen: The New Regressive Leftist Media (New York: Peter Lang, 2020).

21 Crone, Pan-Arab News TV Station al-Mayadeen: The New Regressive Leftist Media.

22 Salamandra, «Past Continuous: The Chronopolitics of Representation in Syrian Television Drama».

23 I Haris al-Quds italesættes styrets hærs generobring af $\emptyset$ staleppo konsekvent som en befrielse. Fx i den omtalte scene, hvor Capucci flere gange fortæller sig selv, at «Aleppo er blevet befriet» [Halab etharraret]. Når jeg bruger formuleringen er det således udtryk for seriens ikke min egen - udlægning af begivenhederne i Aleppo i december 2016.

24 Crisis Group, «Rigged Cars and Barrel Bombs: Aleppo and the State of the Syrian War», Report 155 (9 September 2014).

25 Se fx Salwa Ismail, The Rule of Violence Subjectivity, Memory and Government in Syria (Cambridge: Cambridge University Press, 2018) for en uddybning af hvordan Hama 1982 har været et tabuiseret gennem alle årene og først fra 2011 er blevet italesat.

26 Laleh Khalili, Heroes and Martyrs of Palestine: The Politics of National Commemoration (Cambridge: Cambridge University Press, 2007).

27 Adel Beshara, «Antun Sa'adeh: Architect of Syrian Nationalism», i The Origins of Syrian Nationhood, Histories, Pioneers and Identity, red. Adel Beshara (London New York: Routledge, 2011); Daniel Pipes «Radical Politics and the Syrian Social Nationalist Party”, International Journal of Middle East Studies 20: 303-324 (1988).

28 Nour Samaha, «The Eagles of the Whirlwind», Foreign Policy, March 28, 2016.

29 Crone, Pan-Arab News TV Station al-Mayadeen: The New Regressive Leftist Media.

30 Crone, Pan-Arab News TV Station al-Mayadeen: The New Regressive Leftist Media.

31 For forskellige analyser af sekterianismens skiftende betydning i Syriens modern historie se fx: Raymond Hinnebusch: «Identity and state formation in multi sectarian societies: Between nationalism and sectarianism in Syria», Nations and Nationalism, Vol.26 (2020); Nikolaos van Dam: The Struggle for Power in Syria: Politics and Society Under Asad and the Ba'th Party (London: L. B. Tauris, 2011) eller Christopher Phillips: «Sectarianism and conflict in Syria», Third World Quarterly, Vol. 36, No. 2 (2015).
32 Annika Rabo, «'We are Christians and we are Equal Citizens': Perspectives on Particularity and Pluralism in Contemporary Syria», Islam and Christian-Muslim Relations 23 (1): 79-93 (2012); Andreas Bandak: «Making 'Sound' Analysis From Raw Moments to Attuned Perspectives», i Daniella Kuzmanovic og Andreas Bandak: Qualitative Analysis in the Making (New York: Routledge, 2014).

33 Til trods for at man i en syrisk sammenhæng ikke kan tale om en samlet opposition, er det netop dette styret gør. I spørgsmålet om sekterisme og minoriteter betyder det, at de mange forskellige positioner udviskes for at skabe en fortælling om én intolerant jihadistisk opposition, som systematisk forfølger religiøse minoriteter. 